\title{
NuRSING CARE AND DIETARY PROCEDURES IN THE CASE OF A YOUNG PATIENT DIAGNOSED WITH TYPE 1 DIABETES AND CELIAC DISEASE - CASE STUDY
}

\author{
Anna Piskorz ${ }^{1 \mathrm{~A}, \mathrm{D}, \mathrm{F}}$, Katarzyna Rogowska ${ }^{2 \mathrm{~B}, \mathrm{C}, \mathrm{D}}$, Renata Wolfshaut-Wolak ${ }^{1 \mathrm{E}}$, Iwona Oskędra ${ }^{1 \mathrm{E}}$
}

'Department of Nursing Management and Epidemiological Nursing, Faculty of Health Sciences, Jagiellonian University Medical College, Krakow, Poland

${ }^{2}$ Department of Internal Medicine, Stefan Żeromski Specialist Hospital, Krakow, Poland

Authors' contribution:

A. Study design/planning • B. Data collection/entry • C. Data analysis/statistics $\bullet$ D. Data interpretation $\bullet$ E. Preparation of manuscript $\bullet$ F. Literature analysis/search $\bullet$ G. Funds collection

\author{
Address for correspondence: \\ Anna Piskorz, PhD \\ Department of Nursing Management \\ and Epidemiological Nursing \\ Faculty of Health Sciences \\ Jagiellonian University Medical College \\ 25 Kopernika St., 31-501 Krakow, Poland \\ e-mail: anna.piskorz@uj.edu.pl \\ SUBMITTED: 19.04 .2020 \\ ACCEPTED: 18.06 .2020 \\ DOl: https://doi.org/10.5114/ppiel.2020.98774
}

\begin{abstract}
Introduction: About $15 \%$ of patients diagnosed with type 1 diabetes might also suffer from celiac disease. Celiac disease accompanying type 1 diabetes may lead to the incidence of hypoglycaemia or ketoacidosis and increased risk of complications such as retinopathy and osteoporosis.

Aim of the study: An analysis of the case of a patient suffering from type 1 diabetes and celiac disease and the presentation of a nursing care plan.

Material and methods: The study describes the case of an 18-year-old female patient who had just been diagnosed with type 1 diabetes and celiac and was hospitalised in September 2017. The information about her medical history and condition was obtained by means of an interview, observation, and analysis of medical records with the application of a survey questionnaire, the Visual Analogue Scale (VAS), and the Acceptance of Illness Scale (AIS).

Case description and analysis: The main problems of the patient were connected with celiac symptoms: acute diarrhoea, calf cramps, and overweight caused by dietary mistakes. The patient's deficit of knowledge about dietary procedures had a negative impact on her somatic and mental condition. According to the AIS scale, the patient showed a moderate acceptance towards her illness (a score of 35).

Conclusions: Nursing care provided to patients diagnosed with type 1 diabetes and celiac disease should aim at recognising knowledge and skill deficits, education, and emotional support. Patients' failure to follow dietary recommendations, nutritional deficiencies, and incorrect eating habits frequently result not only from an unwillingness to change eating habits but also from low quality of consumed gluten-free products.

Key words: nursing care, celiac disease, case study, type 1 diabetes.
\end{abstract}

\section{INTRODUCTION}

The importance of genetic factors in type 1 diabetes and celiac disease

Type 1 diabetic patients are often at risk of developing asymptomatic celiac disease. The concomitance of diabetes and celiac disease is determined to a large extent by genetic factors. HLA-DR3-DQ8 and DR4-DQ8 holotypes are characteristic for type 1 diabetes. In celiac disease, on the other hand, HLA-DR3 and HLA-B8 antigens and HLA-DQA1 and HLA-DQ2 alleles and genotypes are the dominant ones. DR3-DQ2 holotypes appear in $80-90 \%$ of celiac patients, and in the case of diabetic patients the risk of the incidence of gluten-sensitive enteropathy increases by as much as 33\% [1-3]. The analyses that have been conducted so far are not unanimous as far as the number of adults and children diagnosed with diabetes and celiac disease is concerned $[4,5]$. Gluten-sensitive enteropathy in type 1 diabetes is more common in women than in men: $99 \%$ and $16.7 \%$, respectively. The symptoms usually appear between the ages of 10 and 45 years, and late diagnosis results from the latent form of the disease. An overt form of celiac disease appears in 13\% of patients on average. The basic symptom of the concomitance of celiac disease in the case of type 1 diabetes is instability in blood glucose level and difficulty in stabilising it. Lack of proper diagnostic procedures and treatment as well as ignoring symptoms lead to the development of diabetic complications such as nephropathy and retinopathy, or celiac complications such as osteoporosis. Proper diet not only reduces the 
risk of these complications but also minimises the risk of death caused by concomitant diseases, which is three times higher than in the case of patients who suffer from diabetes only [1].

\section{Dietary procedures in type 1 diabetes and celiac disease}

Patients suffering from type 1 diabetes and celiac disease should introduce some changes into their diet, which are complex and difficult to apply in practice. A gluten-free diet has a big impact on the control of blood glucose level. According to the research conducted in 2016 by Swensson et al., a well-balanced gluten-free diet may result in lowering the level of glycated haemoglobin by $21 \%$ and decreasing the amount of the insulin taken by a patient [6].

Research into dietary treatment applied in diabetes proved that the effects of blood glucose level control were better in the case of patients following a well-balanced diet based on the glycaemic index (Gl) than in the case of patients applying carbohydrate exchanges [7]. The glycaemic index (GI) is a classification of food products according to their impact on blood glucose level and the time after which this effect can be observed (meal tolerance test). Food products can be divided into three groups: low Gl foods < 55\%, medium Gl foods 55-70\%, and high $\mathrm{Gl}$ foods $>70 \%$. The glycaemic index of gluten and gluten-free products is affected by numerous factors such as the amount and type of carbohydrates, food preparation method, the degree of food fragmentation or degradation of cell membrane structures, and even the degree of fruit ripeness [8]. After an analysis of 12 studies, which examined 612 patients diagnosed with type 1 and 2 diabetes, Thomas et al. proved that lower $\mathrm{Gl}$ values of food products consumed by patients (GI ranging from 38 to $77 \%$ ) resulted in more efficient control of blood glucose level, which was assessed based on the concentration of of $\mathrm{HbA}_{1 c}$ and fructosamine in the serum [7].

In the case of concomitance of diabetes and celiac disease there are problems connected with high GI values and low residue mass of gluten-free products, which are digested and absorbed much faster. Gluten-free products are produced with the application of starches containing much more amylopectin than amylose, which accounts for their alpha-amylase digestion and high Gl values. In order to slow down the digestion process it is necessary to introduce to this diet fibre products dedicated to celiac patients or guar, which, thanks to its gelating properties, significantly impedes digestion, speeds up the intestinal passage, and thus shortens the time of absorption of metabolic products [9].

The study conducted by Segura et al. on the rate of in vitro starch hydrolysis showed that the starch from gluten-free products is usually hydrolysed very rapidly, and GI values of gluten-free bread analysed in the study were very high, ranging from $83.3 \%$ to $96 \%$ [10]. In order to enrich gluten-free bread made mostly from corn flour and rice flour, so-called pseudocereals including amaranth and buckwheat are used in bread baking. They raise the content of minerals, fats, and proteins in products made from socalled European cereals, which are devoid of nutritional value because of the refining process. Another procedure that may increase the content of proteins, fats, and minerals in gluten-free bread is the application in its production of $30 \%$ lupin flour [9].

The Agency for Healthcare Research and Quality at the U.S. Department of Health and Human Services recommends that a gluten-free diet should be based on wholemeal and enriched cereal products, wild rice, and pseudocereals such as amaranth, manioc, millet, quinoa, sorghum, or teff. In turn, the Sydney University Glycaemic Index Research Service (SUGiRS) recommends that low glycaemic index should be the main criterion for choosing food products in the case of a gluten-free diet, and it recommends introducing leguminous vegetables and products made from them to meals as well as eating low-fat yoghurts. Fruits growing in temperate climate such as apples, pears, peaches, plums, and apricots are appropriate in this diet because of their low glycaemic index and pectin content. Due to their low carbohydrate content, leafy greens such as cabbage, lettuce, spinach, cauliflower, and broccoli should be preferred, whereas the intake of root vegetables such as potatoes, sweet potatoes, taro, or yam should be reduced [11].

A group of studies into nutritional deficiencies addresses another problem of a diet therapy. In as many as $30 \%$ of celiac patients were shown to have protein, vitamin, or mineral deficiencies, which resulted from absorption disorders, an imbalanced gluten-free diet, or low quality of gluten-free products (high GI, high content of added sugars and saturated fatty acids, low content of fibre and minerals) [12]. The most frequent problems were calcium (Ca), iron (Fe), and magnesium $(\mathrm{Mg}$ ) deficiencies (because in the course of chronic hyperglycaemia these elements are excessively lost with the urine), and vitamin $B_{12}$ and folic acid shortages $[13,14]$.

In the initial treatment of celiac disease the risk of secondary lactose intolerance must be taken into account, especially in patients who suffer from acute diarrhoea caused by the damage of intestinal villi. In this case a lactose-free diet should be introduced for two or three months [15]. Numerous studies carried out among children, teenagers, and adults suffering from type 1 diabetes and celiac disease indicate frequent occurrence of overweight and obesity in this group of patients $[16,17]$. Nursing type 1 diabetic patients with concomitant celiac disease requires 
a complex assessment of their health needs. These patients not only need emotional support but also reliable information provided by medical staff, including nurses, about how they should act and what is important in the treatment of type 1 diabetes and celiac disease, as well as some instructions on what they can expect during the progress of their disease. In order to improve the quality of patients' health and life it is essential that they cooperate with a dietician on a proper nutrition plan $[12,18]$.

Education is the most important element in diabetic and celiac therapy. It involves promoting a healthy lifestyle, appropriate choice of food products, and self-care skills including elements of pharmacotherapy. Developing new skills and acquiring knowledge about the disease give patients the sense of control over their life and treatment as well as the sense of security and increased quality of life. A diabetic patient is looked after by a variety of specialists. The therapeutic team consists of a doctor, dietician, physiotherapist, psychologist, and a nurse who is the team leader because of her/his professional competences and the frequency of contact with the patient. As the leader of the education process, the nurse should provide patients and their families with basic knowledge so that they could understand important recommendations concerning self-care in their condition and could apply them in practice. It is important to use appropriate vocabulary and teaching materials, and to adjust the pace and the amount of information to patients' intellectual capacity. It is vital to include in the educational process the definition and aetiology of type 1 diabetes and celiac disease as well as information on treatment methods including insulin therapy, measuring blood glucose level, the importance of physical activity, ways of dealing with the incidence of hypoglycaemia or hyperglycaemia, and the choice of food products for diabetic and celiac patients and the methods of preparing them [18]. As far as dietary treatment is concerned, nurses are obliged to discuss the role of particular nutrients and give appropriate examples. They should provide patients with information about the importance of regular meals, the role of dietary fibre, and the necessity to eliminate from their diet products with high glycaemic index or including gluten. Moreover, patients should be informed about the correlation between the blood glucose level and the quality of physical activity. The training should be prepared beforehand taking into account patients' diagnosis as well as the objectives of undertaken actions and a treatment plan. It seems vital to assess the extent to which the patients reach educational goals. Patients' education is a long-term process because the acquired information must be completed and updated along with the advances in medical technology and pharmacology [19].

\section{AIM OF THE STUDY}

An analysis of the case of a patient suffering from type 1 diabetes and celiac disease, and the presentation of a nursing care plan.

\section{MATERIAL AND METHODS}

The study describes the case of an 18-year-old female patient who had just been diagnosed with type 1 diabetes and celiac disease. The study applied the method of a case study and the following research techniques: an interview, observation, and analysis of medical records. The research tools applied in the study included a self-designed questionnaire, the Acceptance of Illness Scale (AIS), and the Visual Analogue Scale (VAS). The survey questionnaire made it possible to analyse the somatic condition of the patient including basic life parameters and anthropometric measurements such as height and weight, and to calculate body mass index.

The Acceptance of Illness Scale was used to assess to what extent the patient accepted her condition. The scale consists of eight statements that describe a possible negative attitude to the illness. The patient's task was to describe her current condition on a five-point Likert scale. The patient may score between the minimum score of 8 and the maximum score of 40 , where $36-40$ denotes a high level of acceptance, 20-35 - an average level of acceptance, and 8-19-a low level of acceptance. The higher the score, the better the patient can adapt to the limitations resulting from their current health condition [20].

The Visual Analogue Scale is a reliable measure to assess the patient's intensity of pain, which allows for the assessment of the efficiency of pain therapy. The scale has a form of a 10-centimetre ruler. Patients show with their finger or a slider the intensity of pain, where 0 means no pain, and 10 - the worst pain possible [21].

The study was carried out in September 2017 in the Specialist Hospital in Krakow. The study received the approval of the hospital authorities. It was conducted during five meetings lasting one hour each. The patient was informed about the aim and form of the study. The patient gave her informed consent to participate in the study.

\section{CASE STUDY}

The subject of the study was an 18-year-old female patient. The respondent lived with her mother in a city in the Małopolska region. She was a thirdyear high school student. The patient was physically fit and independent in everyday life. She was admitted to a local hospital in the city in which she lived because of a fainting episode which resulted from hyperglycaemia. Due to the lack of a specialist diabetic 
ward the patient was referred to another hospital. The study started on the fourth day of the patient's hospitalisation.

\section{Data obtained from the interview and medical records}

The data connected with type 1 diabetes refer to the preceding six months. The patient complained of periodic dizziness, lapses of concentration, and tiredness. In the previous year she had fainted twice during her school classes. These episodes made her mother decide that the patient should see the doctor.

A blood glucose test was taken, and the fasting glucose level reached $166 \mathrm{mg} / \mathrm{dl}(9.22 \mathrm{mmol} / \mathrm{l})$. Another blood glucose test also exceeded the acceptable range. In September 2017 the patient was referred to a diabetology clinic for further diagnosis. The result of an oral glucose tolerance test (OGTT) test taken two hours after drinking glucose solution reached $220 \mathrm{mg} / \mathrm{dl}(12.2 \mathrm{mmol} / \mathrm{l})$ and confirmed diabetes. In the same month, the patient was admitted to the Specialist Hospital and treated on the ward of Metabolic Diseases and Diabetology. During the treatment both the patient and her mother participated in a series of standard training sessions within the School for Diabetics programme, which were run by a team of medical professionals including a doctor, a nurse, and a dietician. The training addressed the problem of measuring blood glucose levels and their interpretation, rules of insulin administering, dietary recommendations appropriate for type 1 diabetes and celiac disease treatment, and preparing an individual nutrition plan.

The patient was treated with insulin therapy with the application of a rapid acting insulin analogue (NovoRapid) and long-acting analogue (Levemir). The medicine dosage was prescribed by a doctor taking into account a full profile of the patient's glucose blood level. Table 1 presents a full profile of the pa- tient's blood glucose level during her hospitalisation. The data show a significant fluctuation of glucose concentration as the blood glucose level measured in the morning and before meals exceeded recommended values of $70-110 \mathrm{mg} / \mathrm{dl}$. Moreover, a high concentration of blood glucose was observed early in the morning (a phenomenon known as the dawn effect). Such a phenomenon is typical of type 1 diabetes patients, especially in adolescence. It results from an increased production of growth hormone by the pituitary gland, which takes place at night [22]. Medical records and an interview with the patient showed that during the previous few weeks she had experienced episodes of hypoglycaemia about two times a week, including hand tremors, hot flushes, and weakness. Additionally, for the last three months the patient had been complaining of diarrhoea and nocturnal calf cramps. The patient was advised to do a serological test. The further diagnostic process showed the presence of HLA-DRB1*04.DQ8 haplotype, which increases the risk of celiac disease.

\section{Assessment of patient's condition}

The assessment of the patient's bio-psycho-social condition was conducted on the basis of an interview, physical examination, and anthropometric measurements. The following observations were made:

1. Respiratory system: Inaudible breathing through the nose, thoracic respiration with the rate of 16 breaths per minute. The patients did not report any respiratory issues.

2. Digestive system: Height: $165 \mathrm{~cm}$, weight: $80 \mathrm{~kg}$, body mass index (BMI): $29.38 \mathrm{~kg} / \mathrm{m}^{2}$, overweight, periodic diarrhoea, normal appetite. The patient had insufficient knowledge about proper nutrition in diabetes and celiac disease. The patient complained of stomach aches that appeared about 30 minutes after a meal. She suffered from diarrhoea with three to five loose stools a day.

Table 1. Glycaemic profile of the examined patient during hospitalisation

\begin{tabular}{|c|c|c|c|c|}
\hline $\begin{array}{l}\text { First day } \\
\text { of hospitalisation }\end{array}$ & $\begin{array}{c}\text { Second day } \\
\text { of hospitalisation }\end{array}$ & $\begin{array}{c}\text { Third day } \\
\text { of hospitalisation }\end{array}$ & $\begin{array}{c}\text { Fourth day } \\
\text { of hospitalisation }\end{array}$ & $\begin{array}{c}\text { Fifth day } \\
\text { hospitalisation } \\
\text { (short profile) }\end{array}$ \\
\hline (before breakfast) & $8: 30$ a.m. $-150 \mathrm{mg} / \mathrm{dl}$ & 8:30 a.m. $-122 \mathrm{mg} / \mathrm{dl}$ & $8: 30$ a.m. $-80 \mathrm{mg} / \mathrm{dl}$ & 11:00 a.m. $-140 \mathrm{mg} / \mathrm{dl}$ \\
\hline 11:00 a.m. - 240 mg/dl & 11:00 a.m. - 244 mg/dl & 11:00 a.m. - 210 mg/dl & 11:00 a.m. - 160 mg/dl & 3:00 p.m. -138 mg/dl \\
\hline 1:00 p.m. - 195 mg/dl & 1:00 p.m. -190 mg/dl & 1:00 p.m. -63 mg/dl & 1:00 p.m. - 112 mg/dl & 7:30 p.m. -122 mg/dl \\
\hline 7:30 p.m. $-240 \mathrm{mg} / \mathrm{dl}$ & 7:30 p.m. $-211 \mathrm{mg} / \mathrm{dl}$ & 7:30 p.m. -200 mg/dl & 7:30 p.m. -134 mg/dl & \\
\hline 9:00 p.m. $-210 \mathrm{mg} / \mathrm{dl}$ & 9:00 p.m. $-190 \mathrm{mg} / \mathrm{dl}$ & 9:00 p.m. -127 mg/dl & 9:00 p.m. -106 mg/dl & \\
\hline 12.00 midnight - & $12: 00$ midnight - & $12: 00$ midnight - & $12: 00$ midnight - & \\
\hline 187 mg/dl & $140 \mathrm{mg} / \mathrm{dl}$ & $103 \mathrm{mg} / \mathrm{dl}$ & 110 mg/dl & \\
\hline 3:30 a.m. -298 mg/dl & 3:30 a.m. $-132 \mathrm{mg} / \mathrm{dl}$ & 3:30 a.m. $-98 \mathrm{mg} / \mathrm{dl}$ & 3:30 a.m. -100 mg/dl & \\
\hline
\end{tabular}

11:00 a.m., 3:00 p.m., 7:30 p.m. -2 hours after the main meal 
3. Cardiovascular system: Blood pressure taken on right arm was 128/76 $\mathrm{mmHg}$ and on the left arm - 124/70 mmHg; strong, firm, and regular pulse with 78 heat beats per minute measured on radial artery.

4. Genitourinary system: The patient did not report any complaints connected with the urinary system. Regular menstruation, first menstrual period at the age of 12 years. The patient was not pregnant.

5. Locomotor system: The patient was independent in everyday routines. She did not take up any physical activity apart from school PE lessons. She reported periodic nocturnal lower leg cramps. The intensity of pain during the cramp was assessed by the patient as 3 on the VAS scale.

6. Nervous system: The patient was conscious, in logical contact with her environment, and aware of the place and time. No pathologies were observed in her nervous system.

7. Skin: Clear, elastic, and dry. No disturbing skin disorders were observed.

8. Sensory nervous system: No abnormalities were observed in the patient.

9. Acceptance of illness: The patient's score and the AIS was 35, which means that she accepted her health condition to a moderate extent. The patient was concerned about dietary limitations connected with type 1 diabetes and celiac disease.

10. Pharmacological treatment: The patient was treated with a rapid-acting insulin analogue and in the evening with a long-acting analogue administered in the form of subcutaneous injections. Oral painkillers were also prescribed in the case of pain. In order to keep the patient hydrated isoionic and isotonic multi-electrolyte fluid IV and $\mathrm{NaCl} 0.9 \%$ were prescribed.

Table 2 presents a nursing plan.

\section{DISCUSSION}

The concomitance of diabetes and celiac disease is determined to a large extent by genetic factors. As many as $80-90 \%$ of celiac patients have holotype DR3-DQ2, and, in the case of diabetic patients, this holotype increases the risk of the incidence of glutensensitive enteropathy by up to $33 \%$. Type 1 diabetes is a very important risk factor that leads to the development of celiac disease in children and young people. The presence of haplotype HLA-DRB1*04.DQ8 predisposing to the incidence of celiac disease was also confirmed in the case of the patient [1-3].

The incidence rate in the group of type 1 diabetes patients approximates $5-8 \%$, and it is higher than in the general population [22]. About $16 \%$ of children suffering from type 1 diabetes have serological markers of celiac diseases: anti-endomysial antibodies or tissue transglutaminase antagonists [23]. In the studies conducted in a group of children and teenagers suffering from type 1 diabetes, celiac disease was found in $2.2-15.1 \%$ of cases, which is 20 times more frequently than in the case of the diabetes-free population [24, 25]. Surveillance studies conducted in European countries and in North America proved that in a group of diabetic children and teenagers, celiac disease was diagnosed simultaneously with type 1 diabetes or within a year from diabetic diagnosis in $60 \%$ of respondents. In the other $40 \%$ of cases celiac disease was diagnosed within 24-36 months after diabetic diagnosis [25]. The studies on the concomitance of celiac disease carried out in a group of adult type 1 diabetic patients led to conflicting results. Some studies conducted in a group of adult type 1 diabetic patients showed that celiac disease was recognised two times less frequently than in the case of children and teenagers. On the other hand, other studies proved that celiac disease is concomitant with type 1 diabetes to the same extent as in the case of children and teenagers, that is in about $12.3-13.8 \%$ of patients $[3,26]$.

Recommendations of the Polish Diabetes Association on diabetic care for children and teenagers issued in 2019 focus only on diagnosing celiac disease according to ESPGHAN guidelines, and if no symptoms are observed within the first 10 years of diabetes, screening tests are recommended every or every other year. However, there are no similar recommendations as far as adults are concerned [27, p. 63]. Concomitant asymptomatic celiac disease and type 1 diabetes in adult patients is a clinical problem that is rarely taken into consideration. Moreover, complicated and costly diagnostics frequently accounts for a delayed diagnosis of celiac disease in adult patients suffering from type 1 diabetes. Every form of celiac disease might have a significant impact on the course of diabetes and the prognosis for patients' life expectancy and quality [26].

The examined case of a young patient diagnosed with type 1 diabetes and celiac disease proves that patients suffering from autoimmune disorders are also likely to suffer from concomitant celiac disease, especially when the clinical picture indicates the incidence of diarrhoea; this was also confirmed by the studies conducted by Bardella et al. [26].

The treatment plan of the examined diabetic and celiac patient should take into account the possibility of eating several gluten-free meals accompanied by a dose of rapid-acting analogue. Such a scheme prevents sudden hypo- and hyperglycaemia incidents, especially during the period of celiac diagnosis. The aforementioned scheme of therapeutic procedures is also confirmed by the study conducted by GalickaLatała et al. [28].

Numerous studies on new methods of treating celiac disease have appeared recently, but these methods 


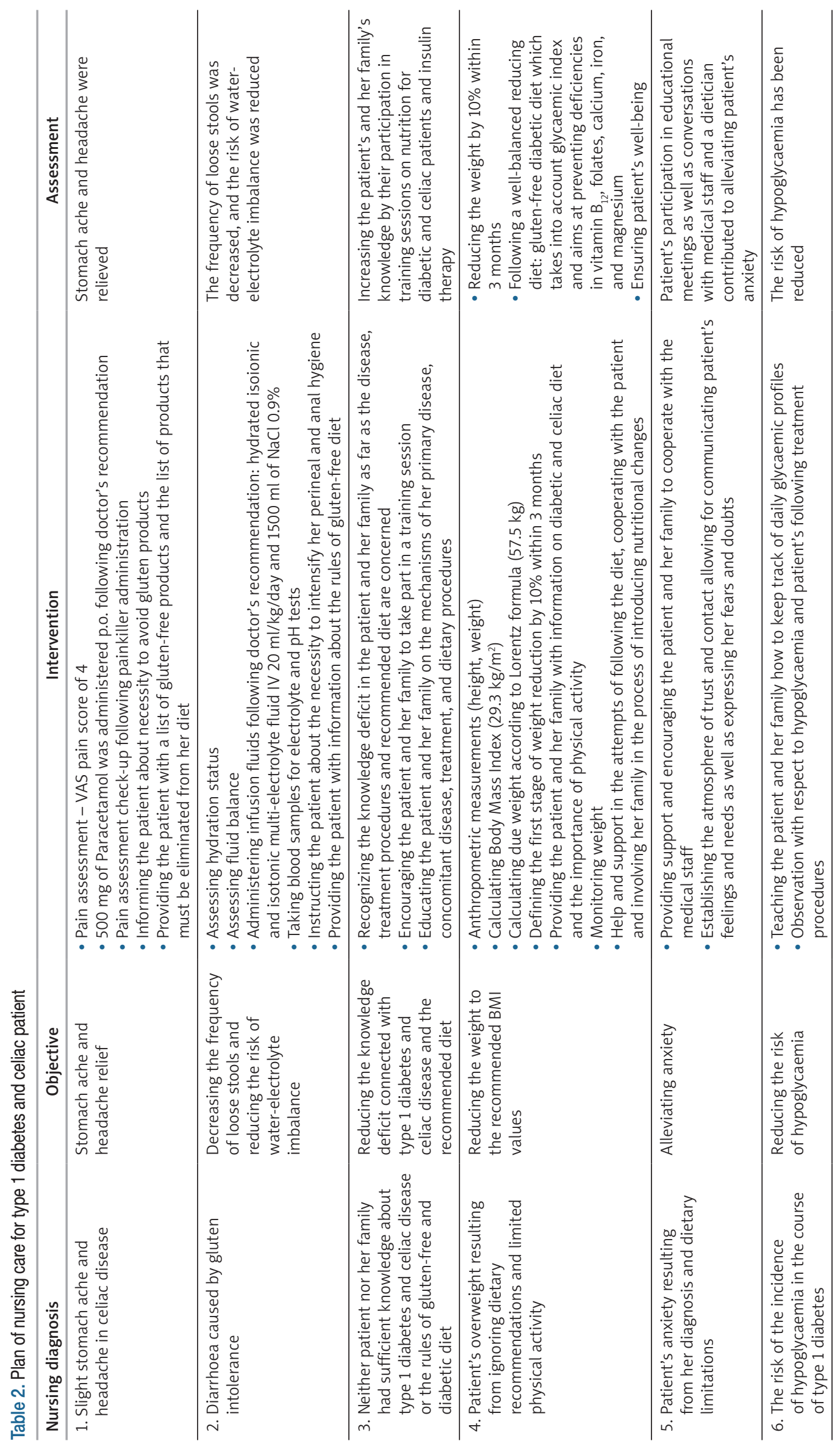


are still in their experimental stage. Nowadays a proper gluten-free diet remains the recommended form of celiac treatment. The findings of the latest studies show that patients often have problems with recognising gluten sources and unknowingly exceed the acceptable daily intake of this protein. It involves the risk of numerous complications including osteoporosis, malocclusion, angular cheilitis, liver functional disorders, or even tumours - small-intestinal adenocarcinoma, mouth cancer, oesophageal cancer, duodenal cancer, or colon cancer [29]. Numerous studies conducted in celiac patients confirm that excess weight and obesity are observed both at the time of the diagnosis and while following a gluten-free diet. After a two-year therapy there was a marked increase in patients' BMI values - from 24.4 to $25.9 \mathrm{~kg} / \mathrm{m}^{2}[16,30]$.

In the examined case the main task of a nurse was to educate the patient and her family on the aetiology of type 1 diabetes and celiac disease, insulin therapy, measuring blood glucose level, the importance of physical activity, ways of dealing with the incidence of hypoglycaemia or hyperglycaemia, and the choice of food products for diabetic and celiac patients. The patient was a young person who found it difficult to follow new medical recommendations. The informative and emotional support of the nursing staff was extremely important for this young patient. It decreased her anxiety resulting from dietary restrictions. Another important aspect that allowed for a positive prognosis for the patient was her acceptance of illness determined by means of AIS scale. The patient's complaints were connected mainly with celiac symptoms (stomach ache and diarrhoea), overweight, deficient knowledge about nutrition in type 1 diabetes and celiac disease, and lack of self-care skills.

\section{CONCLUSIONS}

Diet therapy plays an important role in the treatment of type 1 diabetes and celiac disease. In the case of patients suffering from both type 1 diabetes and celiac disease, following a proper diet requires special dietary consultations, an enormous patients' involvement and an ability to balance a diet.

Patients' failure to follow dietary recommendations, nutritional deficiencies, and bad eating habits (excess weight, obesity) frequently result not only from their lack of acceptance of the disease and unwillingness to change their eating habits, but also from low quality of consumed gluten-free products.

The educational and supportive role of a nurse as well as her or his professional and individual approach to the patient contribute to an improvement in the patient's somatic and psychological condition.

\section{Disclosure}

The authors declare no conflict of interest.

\section{References}

1. Rastogi A, Kumar S, Kochhar BR. Do patients with celiac disease patients differ from those with concurrent celiac disease with type 1 diabetes mellitus? Int J Pediatr Endocrinol 2013; Supl. 1: 1-3. Retrieved from: https://ijpeonline. biomedcentral.com/articles/10.1186/1687-9856-2013-S1-030.

2. Waliłko E, Niemiec A, Majkowska L. Celiakia u dorosłych osób z cukrzycą typu 1. Diabetologia Kliniczna 2014; 3 : 206-211.

3. Szcześniak GR, Zdybel W, Kozak-Nurczyk P, et al. An evaluation of the prevalence of autoimmunological diseases in patients with diabetes and obesity hospitalized in the Department of Diabetology, Rural Medicine Institute in Lublin. Family Medicine \& Primary Care Review 2016; 18 : 345-347.

4. Chwalba A, Otto-Buczkowska E. Role of gluten-free diet in pathogenesis of type 1 diabetes - what new? Pediatr Endocrinol Diabetes Metabolism 2015; 21: 188-191.

5. Tiberti C, Panimolle F, Bonamico $M$, et al. IgA anti-transglutaminase autoantibodies at type 1 diabetes onset are less frequent in adult patients and are associated with a general celiac-specific lower immune response in comparison with nondiabetic celiac patients at diagnosis. Diabetes Care 2012; 35: 2083-2085.

6. Svensson J, Sildor SM, Pipper CB, et al. Potential beneficial effects of a gluten-free diet in newly diagnosed children with type 1 diabetes: a pilot. Sprenger Plus 2016; 5: 1-8.

7. Thomas DE, Elliott EJ. The use of low-glycaemic index diets In diabetes control. Br J Nutr 2010; 104: 797-802.

8. Kulai T, Rashid M. Assessment of nutritional adequacy of packaged gluten-free food products. Can J Diet Pract Res 2014; 75: 186-190.

9. Dudziak K, Regulska-llow B. Znaczenie wartości indeksów glikemicznych produktów bezglutenowych w terapii choroby trzewnej i współistniejącej cukrzycy typu 1. Endokrynologia, Otyłość i Zaburzenia Przemiany Materii 2012; 3: 98-108.

10. Segura ME, Rosell CM. Chemical composition and starch digestibility of different gluten-free breads. Plant Foods Hum Nutr 2011; 3: 224-230.

11. Queiroz KC, Novato SI, de Cassia Gonçalves Alfenas R. Influence of the glycemic index and glycemic load of the diet in the glycemic control of diabetic children and teenagers. Nutr Hosp 2012; 2: 510-515.

12. Szczerba E, Kozłowska A, Nitsch-Osuch A. Leczenie dietetyczne celiakii współistniejące z cukrzycą typu 1. Medycyna Ogólna i Nauki o Zdrowiu 2018; 3: 166-171.

13. Kalayci AG, Kansu A, Girgin N, et al. Bone mineral density and importance of a gluten-free diet in patient with celiac disease in childhood. Pediatric 2001; 108: 1-5.

14. Salmonowicz B, Krzystek-Korpacka M, Noczyńska A. Trace elements magnesium and the efficacy of antioxidant systems in children with type 1 diabetes mellitus and in their siblings. Adv Clin Exp Med 2014; 23: 259-268.

15. Cielecka EK, Dereń K, Grzegorczyk A. Nadwrażliwość pokarmowa. Alergia Astma Immunologia 2010; 15: 118-124.

16. Dickey W, Kearney N. Overweight in celiac disease: prevalence, clinical characteristics, and effect of a gluten-free diet. Am J Gastroenterol 2006; 10: 2356-2359.

17. Tortora R, Capone P, De Stefano G, et al. Metabolic syndrome in patients with celiac disease on a gluten-free diet. Aliment Pharmacol Ther 2015; 41: 352-359.

18. Stefanowicz A, Birkholz D, Wójcicka B, et al. Rola pielęgniarki w edukacji chorego na cukrzycę typu $1 \mathrm{i} /$ lub jego rodziny. Problemy Pielęgniarstwa 2009; 17: 346-349. 
19. Gładyś K, Guzek M, Adrych K, et al. Praktyczne aspekty stosowania diety bezglutenowej u osób z chorobą trzewną. Forum Medycyny Rodzinnej 2015; 9: 447-455.

20. Juczyński Z. Narzędzia pomiaru w Promocji i Psychologii Zdrowia. Wyd. 2. Pracownia Testów Psychologicznych Polskiego Towarzystwa Psychologicznego, Warszawa 2012.

21. Cepuch G, Wordliczek J, Golec A. Wybrane skale do badania natężenia bólu u młodzieży - ocena ich przydatności. Polska Medycyna Paliatywna 2006; 5: 108-113.

22. Ludvigsson JF, Ludvigsson J, Ekbom A, et al. Celiac disease and risk of subsequent type 1 diabetes. Diabetes Care 2006; 29: 2483-2488.

23. Simmons JH, Klingensmith GJ, McFans K, et al. Celiac autoimmunity children with type 1 diabetes: a two year follow-up. J Pediatr 2011; 1578: 276-281.

24. Szlachecki M, Albreht P, Kluzek S. Celiac disease and diabetes mellitus type 1. In Kruzilak P, Bhagat G (eds.). Celiac disease - pathophysiology to advanced therapies. In Tech, Rijeka 2012.

25. Kylökäs A, Kaukine KN, Huhtala H, et al. Type 1 and type 2 diabetes in celiac disease: prevalence and effect on clinical and histological presentation. BMC Gastroenterol 2016; 16: 1-7.

26. Bardella MT, Elli L, De Matteis SD, et al. Autoimmune disorders in patients affected by celiac sprue and inflammatory bowel disease. Ann Med 2009; 41: 139-143.

27. Zalecenia kliniczne dotyczące postępowania $u$ chorych na cukrzycę 2019. Stanowisko Polskiego Towarzystwa Diabetologicznego. Diabetologia Polska 2019; 5: 1-110.

28. Galicka-Latała D, Kozek E, Lorkowski J, et al. Współwystępowanie chorób autoimmunologicznych -opis przypadku. Ostry Dyżur 2009; 3-4: 68-70.

29. Konińska G, Marczewska A, Sabak-Huzior P, Źródlak M (red.). Celiakia i dieta bezglutenowa - praktyczny poradnik. Wyd. 12. Polskie Stowarzyszenie Osób z Celiakią i na Diecie Bezglutenowej. Wydawnictwo Efekt, Warszawa 2017.

30. Kabbani TA, Goldberg A, Kelly CP. Body mass index and the risk of obesity in celiac disease treated with the gluten-free diet. Aliment Pharmacol Ther 2012; 35: 723-729. 